\title{
Lapurdum
}

Euskal ikerketen aldizkaria | Revue d'études basques |

Revista de estudios vascos | Basque studies review

$13 \mid 2009$

Numéro XIII

\section{Datibo komunztadura beti zaindu, inoiz zaindu ez eta batzuetan baino zaintzen ez denean. Hiru ahoko aldagaia, datu iturri bi, eta erreminta bat : Corsintax}

Beatriz Fernández Fernández et Josu Landa

\section{(2) OpenEdition \\ 1 Journals}

Édition électronique

URL : https://journals.openedition.org/lapurdum/2053

DOI : 10.4000/lapurdum.2053

ISSN : 1965-0655

Éditeur

IKER

Édition imprimée

Date de publication : 1 février 2009

Pagination : 159-181

ISBN : 978-2-86781-409-X

ISSN : $1273-3830$

Référence électronique

Beatriz Fernández Fernández eta Josu Landa, «Datibo komunztadura beti zaindu, inoiz zaindu ez eta batzuetan baino zaintzen ez denean. Hiru ahoko aldagaia, datu iturri bi, eta erreminta bat : Corsintax», Lapurdum [Linean], 13 | 2009, Sarean emana---an 15 avril 2013, kontsultatu 29 juillet 2022. URL: http:// journals.openedition.org/lapurdum/2053 ; DOI: https://doi.org/10.4000/lapurdum.2053 


\title{
Datibo komunztadura
} beti zaindu, inoiz zaindu ez eta batzuetan baino zaintzen ez denean. Hiru ahoko aldagaia, datu iturri bi, eta erreminta bat: Corsintax

\author{
Beatriz FERNÁNDEZ \& Josu LANDA \\ UPV/EHU \& Ametzagaiña
}

\section{Abstract}

Gotzon Garate gogoan

In this paper, we analyze dative agreement drop, a phenomenon attested in North-Eastern varieties of Basque. More precisely, we distinguish three main settings of this syntactic variable with respect to agreement obligatoriness. In the first setting, dative agreement is optional. This setting is found with (i.) quirky dative objects in absolutive/dative alternating verbs, (ii.) dative-postpositions in postposition/dative alternating verbs, and (iii.) aspectual datives. In the second setting, dative agreement is obligatory rather than optional, and here we distinguish (iv.) dative-experiencers, (v.) dative-possessors in inalienable possession and ethical datives, and (vi.) causees. The third and last setting corresponds to datives which may never agree, that is, adjunct type datives. We'll obtain the main data from the historical dictionary Mitxelena and Sarasola's (1989-2005) Orotariko Euskal Hiztegia (OEH) and the modern literature corpus Ereduzko Prosa Gaur (EPG). We'll also present a corpus search tool which retrieves syntactic information from this corpus: Corsintax.

1. Lan honek asko zor die urteotan gai honen inguruan gogaide izan ditugun Pablo Albizu eta Jon Ortiz de Urbina lagunei. Baita Mark Baker maisuari ere, Rutgersen 2007 an berarekin batera izandako lan saioengatik. Ibon Sarasolak hitzei eta hitzen adierei buruzko argibide asko eta asko eman dizkigu, eta Maider Bedaxagarrek zuberera edo xiberutarraren adibideez. Bihoakie gure esker ona guztiei. Zortea dugu, benetan, eurak bezalako ikerkide eta lagunak izateagatik. Lanean zehar egon litezkeen okerren erantzukizuna, jakina, gurea baino ez da. Txosten hau hiru ikerketa proiekturi esker idatzi ahal izan dugu: UPV/EHUren EHU06/20, Ministerio de Ciencia e Innovación FFI2008-00240/FILO eta Agence Nationale de la Rechercheren ANR-07-CORP-033 ikerketa proiektuei esker hain zuzen. 


\section{Laburpena}

Lan honetan, datibo komunztaduraren galera aztertuko dugu, euskararen ipar-ekialdeko hizkeretako fenomenoa. Hala, aldagai sintaktiko honen hiru burutzapen bereiziko ditugu. Hautazko datibo komunztadura erakusten duten datiboak aztertuko ditugu lehenik: (i.) datibo-osagarri bitxiak absolutibo/datibo alternantziadun aditzetan, (ii.) datibo-postposizioak datibo/postposizio alternantziadun aditzetan, eta (iii.) aspektu datiboak. Bigarrenik, ezinbesteko komunztadura duten datiboak, alegia, (iv.) datibo esperimentatzaileak (v.) jabetza besterenezineko datiboak, datibo etiko eta interes datiboak, eta (vi.) egitura arazleetako araziak. Hirugarren eta azkenik, ezinezko komunztadura duten datiboak deskribatuko ditugu, hau da, (vii.) datibo-adjunktuak. Deskribapenerako batetik, Mitxelena eta Sarasolaren (1989-2005) Orotariko Euskal Hiztegiaz (OEH) baliatuko gara, eta bestetik, Ereduzko Prosa Gaur (EPG) corpusaz. Corpus honetatik informazio sintaktikoa erauzteko, Corsintax arakatzaile sintaktikoa ere plazaratuko dugu.

\section{Keywords}

Dative, agreement, dative agreement, dative agreement drop, syntactic variation.

Gako hitzak

Datiboa, komunztadura, datibo komunztadura, datibo komunztaduraren galera, aldakortasun sintaktikoa.

\section{Atarikoak}

Euskalkien arteko aldakortasun sintaktikoari begiratzen diogunean, argiro banatzen ditu iparekialdeko hizkerak hego-mendebaldekoetatik datibo komunztadura galerak. Aldagai sintaktiko hau, salbuespenak salbuespen (Gèze 1873, Hualde eta Ortiz de Urbina 1987, Ortiz de Urbina 1995, Fernández 1997, Albizu 2001) gutxitan aipatu eta aztertu izan da gramatikagintzan, aspaldi honetan bide berriak urratu diren arren -Etxepare eta Oihartzabal (2008a,b,c), eta Fernández eta Ortiz de Urbina (2008).

Guk bide berri horiek esploratu nahian erakutsiko dugunez, ipar-ekialdeko hizkeretan, alegia, datibo komunztaduraren galera duten hizkera horietan bertan, badira datibo komunztadura beti zaintzen duten datiboak, inoiz ere zaintzen ez dutenak eta batzuetan baino zaintzen ez dutenak. Aldagai sintaktiko honek, beraz, hiru aho ditu, eta halaxe dela ikusiko dugu euskararen iragan eta orainari begiratuz. Horretarako, batetik, Mitxelena eta Sarasolaren (1989-2005) Orotariko Euskal Hiztegiaz (OEH) baliatuko gara, eta bestetik, Ereduzko Prosa Gaur (EPG) corpusaz.

Bigarren datu iturri hori (EPG) arakatzeko erreminta ere plazaratuko dugu, corpusetatik informazio sintaktikoa erauzteko baliagarria dena: Corsintax. Sintaxiari lotutako aldagai askoren informazio emaile izan badaiteke ere, oraingoan datibo komunztaduraren zaintzeari eta ez zaintzeari buruzko datuetara mugatuko da emaitza.

\section{Datibo komunztadura, hiru ahoko aldagaia}

Datibo komunztadura ipar-ekialdeko hizkeretan ez da ez zoriz ez nonahi galtzen. Datibo komunztadura hizkera hauetan hiru ahoko aldagaia dela uste dugu guk: badira datibo komunztadura beti zaintzen duten datiboak (d,e,f), inoiz ere zaintzen ez dutenak (g) eta batzuetan baino zaintzen ez dutenak (a,b,c).

(1) a. Ihesari eman nahi dire, bainan nondik eskapa (Arb Igand 79)

b. Etzieztela fida amodioari! (ChantP 198)

c. Jarraiki ziren beraz aintzina izar hari (Jnn SBi 16) 
d. Eta Jainkoari etzaio ahantziko (Dv Lab 10)

e. Mailez-mail gorphutz guzia kaskaka uspeltzen zaio martir berri huni (Arb Ignd 87)

f. Iñaziok, hitzik erran gabe, Calistori eta Caserori soineko ilhun bat har arazi zioten (Laph 85)

g. Zuek ordean hurbildu zarete Siongo mendiari, eta Jainko biziaren hiriari, zeruko Jerusalemeri, eta asko miletako aingeru multzoaren gana, 23. nausitasuna. (Dv Hebr 12, 22 $-\mathrm{KG}-$ )

Hortaz, datibo komunztadura hautazkoa ez ezik, halabeharrezkoa ere bada batzuetan, eta hori nahikoa ez eta bestetan, oso bestela, ezinezkoa ere bada.

Komunztadura inoiz baino zaintzen ez den kasuetan, aspektu datiboak (a), datibo-postposizioak datibo/postposizio alternantziadun aditzetan (b) eta datibo-osagarri bitxiena aztertuko ditugu lehenik (c), neurri batean Ortiz de Urbinaren (1995) lanari jarraituz. Bigarrenik, komunztadura beti zaintzen duten datiboak deskribatuko ditugu, lehenik datibo esperimentatzailedun inakusatiboak (d), bigarrenik jabetza besterenezineko datiboak, datibo etiko eta interes datiboak (e), eta hirugarrenik egitura arazleetako araziak (f). Azkenik, komunztadura inoiz ere zaintzen ez dituzten datiboetara joko dugu, alegia, leku-datiboetara eta, oro har, datibo-adjunktuetara (g). Lan honetan ez ditugu aztertuko postposizioek hautatzen dituzten datiboak, Etxepare \& Oihartzabalek (2008c) jarraian aztertuko dituztenak.

\section{Datibo komunztadura batzuetan baino zaintzen ez denean (edo datibo komunzta- duraren hautazkotasuna)}

Hiru dira datibo komunztadura batzuetan baino zaintzen ez duten datiboak, edo, nahiago bada, hautazko komunztadura erakusten dutenak: aspektu datiboak (2.1), datibo-postposizioak datibo/postposizio alternantziadun aditzetan (2.2) eta absolutibo/datibo alternantziadun aditzen datibo-osagarri bitxiak. Datibo hauen banaketa Ortiz de Urbinak (1995: 586) egindako sailkapen hirukoitzaren ${ }^{2}$ garapena da neurri batean, eta bertatik abiatuko gara atal honetan. ${ }^{3}$

Hautazko komunztaduradun datiboak erakusten dituzten aditzak, salbuespenak salbuespen, datibodun inakusatiboak dira eta absolutibo-datibo hurrenkerakoak, gainera. Hauetariko batzuk dira, hain zuzen, nola edo hala gaiari buruzko literaturan aipatu izan direnak. Hori espero izatekoa da kontuan hartzen badugu halako formak direla ipar-ekialdeko hizkeretan nagusitzen direnak, hego-mendebaldekoetan datibodun inergatiboak, alegia, ergatibo-datibo konfiguraziokoak gailentzen diren bitartean (Fernández eta Ortiz de Urbina 2010; Mounole 2008).

\subsection{Aspektu datiboak: Ari (izan), bermatu, jo, lotu, eman, hasi eta ausartu bakarti bat}

Hasi gaitezen aspektu datiboekin. Ortiz de Urbinak ekintza datiboak deritze. Hauek ulertzeko,

2. Kasuistika zehatzik egin asmorik ez duela dio, eta azalpenaren muina ere ez dela gaineratzen du. Dena den, erakutsiko dugunez, egileak sailkapenari aitortzen diona baino balio handiagoa duelakoan gaude, ñabardurak alde batera.

3. Ortiz de Urbinaren sailkapen hirukoitzaren azpian dagoen hipotesia da komunztadura urratzen duten datiboak sarritan ez direla kanonikoak theta-rolari dagokionez, baldin eta kanonikotzat har daitezkeen datiboak helburuak edota esperimentatzaileak badira. Hortaz, bai lan honetan bai Hualde eta Ortiz de Urbina (1987) lan goiztiarragoan, datibo komunztadura galtzea arrazoi berari egozten zaio, hau da, datibo ez-kanonikoak izateari theta-rolari dagokionez -ikus baita 4 oin-oharra. 
dio, kontuan hartu beharra dugu inesibo postposizioaz marka daitezkeela euskaraz ekintza adierazten duten argumentuak, esate batera, lanean ari zen suharki adibidean, lan argumentuari inesiboa gaineratu zaio. Lanean horrek, baina, badu datibodun ordaina -lanari ari zen suharki (Lafitte 1979: 422)- eta ekintza da, Ortiz de Urbinaren ustez, adierazten duena -hortik ematen dien ekintza datibo deitura ${ }^{4}$. Guk ez dugu hemen ukatuko ekintza datiboak direnik bertara dakartzagunak, baina ari (izan) bera eta ondoren aztertuko ditugunak aspektu aditzak direla pentsatzen dugu, aspektu progresibodunak -ari (izan), jo baita ziur aski bermatu ere- eta aspektu inkoatibodunak -eman eta lotu-, eta hortaz aditz hauekin agertzen diren datiboak aspektu datiboak direla uste dugu. Ildo honetan, gehiago lerratzen gara Etxepare \& Oihartzabalen (2008a) ustera, Ortiz de Urbinarengandik apur bat bereiziz.

Halako datiboak bermatu, ausartu, jo eta lothu aditzekin aurki daitezkeela dio Ortiz de Urbinak. Ikus ditzagun adibide batzuk jarraian:

(2) a. Laborariak bere ahal guziaz bermatu behar du lanari (Dv Lab 389)

b. Ni ez naiz ausartatzen lan horri (Dv Lab 339)

c. Plazan hazkarki jo dezala pilotari (Arb Igand 141)

d. Biharamunetik erlea lanari lotzen da (Dv Lab 297)

Datibo hauetatik lehena bermatu aditzarekin ageri da (a), eta salbuespena da Duvoisinen hizkeran bertan ere. Egia esan OEH hiztegia arakatu eta gero, ez dugu halako aspektu datibo gehiago aurkitu bermatu aditzarekin. Hori hiztegiaren beraren ezaugarriengatik izan daiteke eta ez horrenbeste, bermatu aditzak halakoxe agerpenik ez izateagatik. Baina ez dirudi: OEHtik aparte ere, adibide bakanak baino ez baitditugu aurkitu, eta osagarria datibodun nominalizazioa dutenak, hala nola, ondokoa ${ }^{5}$, Herria osoan bakarra:

(3) Euskal berezitasunaren beiratzeari bermatzen dela erran du bainan bortizkeria gaingainetik baztertuz (Herria, Jean Arotcarena, 2003-11-27, 4 -EPG-)

Entzulea ohartuko zenez, nominalizaziodun osagarria da bermatuk adibidean erakusten duena. Oso litekeena da Leonen ondokoa ere, nominalizaioduna ikusiko denez, halakoxe aspektu datiboa izatea.

(4) Nahigabeak jasan behar ditutzunaz geroz eta ororen buruan hil, -jasaiteari bermatzen bazira eta ontsa hiltzeari jartzen, laster hobetuko zira eta bakea kausituko duzu (Leon Imit II 12, 12 $-\mathrm{KG}-$ )

Egia esan, inkoatiboa ala progresiboa ote den zalantzak ditugu, nahiz eta progresiboa dirudien ${ }^{6}$.

4. Izan ere, adibide hau bera da Hualde eta Ortiz de Urbinak (1987: 433) aipatzen dutena ari izan egituraren gaineko lanean, eta Lafitterena bezalako adibidean, datibo argumentua izanagatik ere, aditz laguntzailean komunztadura zaintzen ez dela oharturik, horren arrazoia datiboari ezartzen zaion argumentuaren thetarolari egozten diote: datibo argumentuek helburu edota onuradun theta-rola izaten dute, baina Lafitteren adibidean, datiboak ez du ez helburu ezta onuradun theta-rolik, eta horrek azaltzen du, euren iritziz, zergatik ez duen komunztadurarik eragiten aditz laguntzailean, eta era berean, zergatik txandakatu daitekeen antzeko egituretan arrunta den inesiboarekin -lanean ari zen suharki.

5. Halakoa da Etxepare \& Oihartzabalen (2008a) Horren hedatzeari bermatu zen adibidea ere.

6. Testuzaleek esaldi beraren hiru bertsio erka ditzakete erabakitzeko. Leonenarekin (1929), Pouvreauren (1669) edota Xurioren (1720) ondokoak, hurrenez hurren, erka daitezke: a) Iarten bazara egiten behar duzunaren egiten, erran nahi da, pairatzen eta zure buruari hiltzen, sarri hobeki izanen zara eta bakea edirenen duzu, eta b) Ematen bazare behar zaren bezala pairatzeko, eta hilltzeko estatuan, kausituko zare berehala hobeki, eta ardietsiko duzu bihotzeko bakea. Progresiboa, ezta? Hala dirudi. 
Ausartu aditza (b) misteriotsuagoa da, Duvoisinen hizkeran ere ez da behin baino ageri, eta hapax sintaktiko bat dirudi, ez baitugu halako beste datiborik aurkitu ez OEHn, ez EPGn ez Klasikoen Gordailua (KG) osorik arakatuta ere.

Jo aditza da zerrendan hurrena. Arbelbideren goiko adibidean, ekinen antzeko jo aditza dugu, eta gutxitxo dira halakoak OEHn (X: 237) ${ }^{7}$. Osagarria zehazten dutenen artean, Eta jo biak lanari (Barb Leg 128) datiboduna ez ezik, Lanian gogor jo zuten (EusJok 122) eta Eskualdun haur lagunak, jo bethi pilotan! (Ox 181) inesibodunak ere jasotzen dira. Inesiboaren eta datiboaren arteko alternantzia ikus daiteke hemen ere osagarriaren markapenean. Etxepare \& Oihartzabalek (2008a) ildo bereko To Ferrando, jozak lanari adibidea dakarte. Duvoisinek honelako ihesari osagarridunak dauzka komunztadurarik gabe:

(5) Aingeruaren oihura ihesari jo dute populuek, eta zure altxatzeari alde orotara itzuri ${ }^{8}$ dira jendaiak (Dv Is 33, 3 -KG-)

Lotu aditzak, Ortiz de Urbinaren zerrendan azkenak, nahi beste adibide eskaintzen dizkigu datiboarekin batera, eta horietatik asko eta asko datibo komunztadurarik gabeak dira gainera ${ }^{9}$. Lotu aditzaren beste adibide batzuk dira ondokoak, komunztadurarik gabeak guztiak.

(6) a. Eta bi gazteak lothu ziren bideari (Zerb IxtS 61)

b. Berehala lehen urratsei lotu ziren (HU Aurp 104s)

c. Lotzen dire berriz janari (HU Zez 131)

d. Bertze solas bati lotu ziren (StPierre 21)

e. Bi bozetan lot gaiten zure kantu horri (Iratz 85)

Horrek ez du esan nahi, jakina, datibo komunztaduradunik ez dagoenik. Ikusi bestela:

(7) a. Lot zakizko Jainkoak manatzen darotzun lanari (Ch I 20,8)

b. Azkenean, lothu zitzaion bideari, harturik berekin bere emaztea ( $\operatorname{Lg}$ I 237)

c. Eta fite zaio ihesari lotzen (Gy 127)

d. Gazteak, haatik, berriz ere lotu zaizkio borrokari (Mde Pr 286)

Irakurleak ikusiko zuenez, hemen osagarria ez da nahitaez lanari, Ortiz de Urbinak jasotako adibideetan nagusitzen dena ${ }^{10}$, ez bada bideari, urratsei, janari eta abar. Jan, solas, kantu, ihes, borroka bezalakoetan, ekintza argumentuak ditugula dirudi, baina hori baino areago, aspektu kutsua da hemen datiboari antzematen dioguna, goian esan dugun bezala, ekintzaren hasiera baita adierazten dena, hau da, aspektu inkoatiboa. Kontuan izan lotu aditzaren forma iragangaitza dela hemen aipa-

7. Ortiz de Urbinak dakarren adibidea jo dezagun bihotzez lanari da, baina erratu esanguratsu bat dago bertan, jatorrizko testuak jo dezogun bihotzez lanari (Dv Lab 31) baitio, ez jo dezagun. Dezogun -datibo komunztaduraduna-izaki liburuak berez dakarrena, eta ez dezagun -datibo komunztadurarik gabea-aspektu datibotzat har dezakegu, jakina, baina ez datibo komunztadura urratzen duen datibotzat. Jo dezogun lanari horren erakusgarri gehiago ditu, gainera, Lab 79 eta Neh 4, 21.

8. Itzuri (Escapar, huir; evitar, escapar a; librarse, salvarse OEH IX:751) ere datibo komunztadurarik gabea da, ikusten denez.

9. Ortiz de Urbinak aipatzen dituen zazpi adibideetatik lautan jasotzen da lotu aditza. Esanguratsua da hori.

10. Mintzagai dugun Ortiz de Urbinaren lanean (1995: 586) aipatzen diren zazpi adibidetatik bostetan lan izena ageri da. 
gai duguna, ekinen esanahitik ${ }^{11}$ gertu dagoena ${ }^{12}$.

Antzera esan genezake eman aditzaz ere: ekin eta lotu aditzen esanahia ere biltzen du, aspektu inkoatiboa zehazten du eta datibo komunztadura nabarmen galtzen duten horietakoa da bere datibo osagarria ${ }^{13}$. Gogoratu Pikabeak (1993: 113) dioen moduan, eman, lotu bezala -baita jarraiki ere, geroago ikusiko dugunez-, tradizioz datiboa erakusten duten aditzetako bat dela, eta orobat, datibo komunztadura zaindu ala urratzeko joeran aldakortasun gehien erakusten dutenetakoa. Ondokoak datibo komunztadurarik gabeak dira:

(8) a. Ihesari eman nahi dire, bainan nondik eskapa (Arb Igand 79)

b. Eman zaite Mariaren debozioneari (MarIl 31)

c.Jendaki guzia tzarkeriari eman zen (Zerb IxtS 13)

Eta datibo komunztaduradunak, berriz, hauexek:

(9) a. Ikharatu zituzten filistindarrak non eman baitzitzaizkon ihesari (Lg I 26)

b. Gogoetari ematen zaizko (Mih 71)

Kontuan izan eman aditzak ere, lothu aditzak bezalaxe, badituela antzeko inesibodun adibideak, hala nola, ondoko hauek:

(10) a. Ardiak deskantsuan mendian utzirik, Bidian emaiten niz makila harturik (Etcham 194)

b. Hango oihanetan lanean eman zen (Lf ELit $254-\mathrm{KG}-$ )

c. Lanean loth gaiten, gu gure partetik, Eta listorrak beretik (Gy 190)

d. (Botoila pausatzen du tonba baten gainean, eta haren aintzinean belauniko, otoitzean lotzen zaio) Alo, idek-hadi, idek, gaizoa (Larz Bordaxuri 55 -KG-)

Hau da, gorago beste aspektu aditzekin ikusi duguna erakusten dute baita eman edota lotu aditzek ere, aspektu datiboak direlako hipotesia indartuz. Larzabalen adibidea (d), bestalde, benetan harrigarria da gure begietara -eta hala behar luke komunztaduraz ardura duen edozeinentzat: inesibodun osagarria dakar lotu aditzak -halako aditzetan espero izatekoa dena datiboarekin alternantzian-, baina hona hemen gure harriduraren zergatia: datibo komunztaduraduna da inesibo osagarria! Ez dugu esango, momentuz, ezer orokortu daitekeenik honetatik, baina halako datibo komunztaduradun inesiboak jasoak dituzte Fernández eta Ortiz de Urbinak (2010) antzeko egitu-

11. Lotu (L, B, S) 'Emprender, ponerse a, darle a' esanahiaz jasotzen du OEH-k (XI: 722).

12. Ez da hau loturen forma iragangaitz bakarra. Bada zentzazio edota gaixotasunei dagokien 'se prendre, se contracter' adiera. Bertan datibo komunztadura galtzen ez dela dirudien arren, adibideek zalantzak sortzen dizkigute bi arrazoirengatik. Batetik, adibide gehienetan, datibo argumentua ez dago agerian. Hortaz, datibo komunztadura zaintzea datibo argumentua bera ez agertzeari egotz dakioke, esate batera Ifernuko errabia bat lothuren zeraio (Dv Led 192) adibidean. Bestetik, datibo argumentua agerian dagoen adibideak XIX. mendea baino lehenagokoak dira, esate batera, Eta arima guziari beldurtasun lot zekion (Lç Act 2, 43), datibo komunztaduraren galera lapurterara zabaldu baino lehenagokoak alegia.

13. Paradoxikoki, ez dirudi ekin adieraz eta formaz horren antzekoa izanik, datibo komunztadura galtzen dutenen artean aipa daitekeenik -Pikabeak ez du aipatzen eta, oro har, ez da bere aipamenik gaia ukitzen duten lanetan ere. Geuk ere OEHri begira ez dugu aurkitu ekin aditzarekin galeraren aztarnarik. Gogoan izan, ekinek forma sintetikoak baino ez zituela erakusten XVI. mendean, eta subjunktibo eta aginterazkoak zirela, hain zuzen, lehen testigantzetan ageri ziren haiek. Forma sintetikoak izanik historikoki nagusitzen direnak, ez dirudi harrigarria denik datibo komunztadura galeraren aztarnarik erakusten ez duten aditzetakoa izatea. Tamalez, ekin aditzaz dioguna ezin daiteke aditz guztiez esan. Jarraiki aditzak, esate batera, forma sintetikoak baditu historikoki, baina datibo komunztadura galera nabarmena erakusten du, ondoren erakutsiko dugunez. 
retan, hala nola, ekin eiozu ebagiten (Ur (V) Apoc 14, 15) edota ari izanen oso gertuko margozten daragoiola (Enb 61) edota iolasean daragoionean (Ibiñ Virgil 109). Azken biotan, aditzaren forma sintetikoan ihartutako datibo komunztadura ez ote dugun pentsa genezake, baina ez dirudi berdin esan daitekeenik ez Uriarteren adibideaz ez Larzabalenaz. Bego momentuz.

Ildo nagusira itzulita ikusten denez, bi aspektuak, progresiboa -ari (izan), jo eta bermatu- eta inkoatiboa -lotu eta eman- erakutsi ditugu adibideotan. Bada aspektu inkoatiboa garbiro erakusten duen beste predikaturik, hasi alegia, Lafittek bere gramatikan (1979: 422) dioenez, datiboaz lagundurik agertzen dena ${ }^{14}$ :

(11) Hasi zen bere sailari

Hasi aditzarekin, bi adibide besterik ez dugu topatu:

(12) a. Hortzez eta haginez hasi nintzen lan horri (Zerb Bahnar 24. kap, Eskualduna, 193508-30, 4 -KG-)

b. Huna nolaz hasi zen buru-lan huni: Euskal-Herrian, urte heietan, bazen asko solas eta kalapita ere, batzu Ameriketarat joaitearen alde, bertze batzu kontra (Larz Hiru 233 $-\mathrm{KG}-$ )

Laburbilduz, datibo komunztadura urratzeko joera dutela erakusten dute aspektu aditz hauen guztien datiboek. Inesiboarekin alternantzian agertzen diren datiboak dira guztiak. Aditz hauek, baita ziur aski ausartuk berak ere bere bakardadean, ederto erakusten dute aspektu aditzak direla. Ari (izan), bermatu, jo eta lotu aditzen zerrendara, eman eta hasi ere gaineratu daitezke. Geroago ikusiko duzunez, oso litekeena da jarraiki aditzak ere aspektu progresibodunetako bat ere izatea.

\subsection{Datibo-postposizioak datibo/postposizio alternantziadun predikatuetan}

Goazen, bada, aurrera. Ortiz de Urbinak bereizten duen bigarren datibo ez-kanonikoen saila zeharkako datiboek osatzen dute, bere deitura erabiliz ${ }^{15}$. Datibo hauek, dioenez, beste euskalkietan zehar kasuen edota, nahiago bada, postposizioen bitartez adierazten dira, eta hortik ematen die deitura. Guk datibo-postposizioak deituko diegu deitura argiagoa delakoan, areago kontuan hartzen badugu nagusiki halako datiboak direla, hain zuzen, Fernández eta Ortiz de Urbinak (2010), datibo/postposizio alternantziadun aditzak deritzetenekin agertzen diren datiboak.

Sail honetan ohartu aditza da Ortiz de Urbinak aipatzen duen ia bakarra, nahiz eta sinestu eta urrikaldu ere harira dakartzan, geroago ikusiko dugunez. Fernández eta Ortiz de Urbinaren sailkapenean (2010), ohartu eta urrikaldu datibo/postposizio alternantzia erakusten duten aditz horietakoak dira. Ikus dezagun bada, datibo komunztadurarekin nola jokatzen duten aditzok adibideen bitartez. Datibo komunztadurarik gabeak dira ondokoak, Duvoisinenak biak.

(13) a. Gauza horri ohartu direnak (Dv Lab 80)

b. Ez nintzen horri ohartzen (Dv Lab 369)

Gogoratu, dena den, XIX. mendea baino lehenagoko autore lapurtarrek ondo zaintzen dutela datibo komunztadura, Leizarragak berak adibidez:

(14) Eta bere buruari ohart ${ }^{16}$ zekionean, erran zezan (Lç 15, 17)

14. Hualde eta Ortiz de Urbinaren lanean (1987: 433) ere aipatzen da bera. Aldiz, Etxepare eta Oihartzabalek (2008a) ere ez dute aipatzen.

15. Gogoan izan Duvoisinen Lab liburua lanetik jasotako datiboak darabiltzala bere sailkapenerako.

16. Bere buruari ohartu esapideak "recobrar el conocimiento" esanahia du, OEHk (XIII: 10) dakarrenez. 
Orain datozenak, berriz, XIX. mendeko lapurteraren testigantzak dira, datibo komunztadura urratzen dutenak (a-c), nahiz eta zaintzen dutenak ere badiren (d):

(15) a. Belhauniko dagolarik, ohartzen da mendi harritsu bati (Lp 40)

b. Ohartu zen munstro irudi bati (MarIl 70)

c. Ohart gaiten berehala deputatuen hamabi ehun nombre horri (Elsb Fram 58)

d. Huntan ohart gaizkon erran xaharrari (Zby 765)

Eta bietara aurki daitezke egile beraren testuetan ere:

(16) a. Ohartu zen behin jendea lehen inarros aldiari (HU Zez 14)

b. Nola ohart dakioken zakur errabiatuari? (HU Gontz $276-\mathrm{KG}-$ )

Urrikaldu edota sinestu aditzak ere oharturekin batera sailka daitezkeela dio Ortiz de Urbinak, goian esan dugunez. Izan gogoan urrikaldu eta ohartu aditz bietan intrumental berrizaleak jatorrizko datiboa ordezkatu duela historian zehar. Urrikalduri dagokionez, ez dirudi ugari direnik datibo komunztadurarik gabeko adibideak, ez behintzat, OEHk (XV: 859-860) edota Pikabeak (1993: 146-147) dakartzatenak kontuan izanda. Horrek ez du esan nahi datibo komunztadura aukeran galdu ezin daitekeenik, jakina. Ortiz de Urbinak dakarren Duvoisinen urrikal zaite niri ${ }^{17}$ adibideaz gain, hauexek (a,b) ere baditugu, ezagunak zaizkigun datibo komunztaduradunekin (c,d) konpara daitezkeenak:

(17) a. Aingeruei hagitz zaizte arimak urrikaltzen (EZ Man I 123)

b. Jauna, urrikal zite / gure manerari (Bordel 43)

c. Othoi urrikal nakizu (Laph 209)

d. Urrikal zakizkigu, Jesus (Dh 80)

Sinestu aditzak, bestalde, urrikaldu edota ohartuk ez bezala, ez dirudi berez datiboa erakusten duenik, ez, behintzat, Duvoisinek darabilen adieran ${ }^{18}$ :

(18) a. Sinesten dut Jainko bati, Aita guziz botheretsuari, zeru lurren Egileari (Dv LEd 8)

Ez gara atrebitzen beste hapax sintaktiko bat dela esaten, baina ez bada ez zaio oso urruti ibiliko. Guk behintzat ez dugu beste adibiderik topatu ez KGn ez EPGn.

Datibo-postposizio sorta honetan gaineratu genitzake dudarik gabe baita Fernández eta Ortiz de Urbinak (2010) datibo/postposizio alternantziadun aditzen artean sailkatu dituzten beste batzuk ere, hala nola, fidatu, bermatu edota pentsatu ${ }^{19}$. Gogoratu aditz hauetan, osagarriak jasotzen duen jatorrizko forma postposizioduna dela -inesiboa, adibidez, fidatu aditzerako eta inesiboa ez ezik, instrumentala edo adlatiboa ere pentsatu aditzerako-, eta postposizio hauek ordezkatzen dituen datibo berritzailea dela -historikoki esan nahi dugu- osagarria markatzen hasiko dena. Aditz hauetatik edozeinek erakusten ditu datibo komunztadura galeraren, edo nahiago bada, hautazkotasunaren aztarnak. Ez dira gutxi, adibidez, fidatuk erakusten dituenak, nahiz eta kontuan hartu behar den aditz honekin batera datorren osagarria datiboaz markatzeko joera berritzailea denez, oro har,

17. Deigarria da: Duvoisinen urrikal zaite niri adibideak (a) urrikal zakizkit niri eta (b) urrikal zaite nitaz (Dv LEd 276) perpausen erdibidean sortutakoa dirudi, (a)-n bezala, niri datibo sintagma erakusten duelako, nahiz eta datibo komunztadurarik zaintzen ez duen, nitaz postposizioak (b), jakina, zaintzen ez duen bezala.

18. Ez du horrek esan nahi (zuri) sinesten dizut esan ezin daitekeenik, "creer a alguien" adieran. Adiera honetan, absolutibo/datibo alternantzia duen aditza da sinestu. Euskalkien araberako alternantzia da bera.

19. Trebatu aditzak are agerpen gutxiago dauka datibo osagarriarekin, beste aditz hauek baino. Erakusgarri horietan trebatu aditza forma jokatugabean agertzen denez OEHn, ezin daiteke jakin komunztadurara begira nola jokatzen duen. Gogoan izateko moduko aditza da. 
ez direla horrenbeste datibo osagarria erakusten duten adibideak, OEHn behintzat:

(19) a. Iinkoari nahi ezpazira fidatu, nori nahi zira fidatu? (Tt Arima 122)

b. Ez gaitela, to, fida / lausenguari (Zby RIEV 1908, 759)

c. Holako jender ez da sekulan fidatu behar (Laph 82)

d. Etzieztela fida amodioari! (ChantP 198)

Berriro ere, datibo komunztadurarik erakusten ez duten adibideen ondoan, komunztaduradunak ere aurkituko ditu irakurleak:

(20) a. Ene beharretan eziñ bertze nihori fida nakioke zuri baizen (Ch III 59)

b. Miriku bati fidatzen gaizko osasunaz (Dh 235)

c. Fida hakit arras niri (Gy 42)

Bermatu ere datibo/posposizio alternantziadun aditza da -ez da hau gure lehengo bermatu aspektu aditza. Fidatu aditzarekin bezalatsu, inesiboa da datiboak ordezkatu duena. Ondoko adibide hauek guztiak datibo komunztadurarik gabeak dira:

(21) a. Ama Jainkoarenak, / Saragozen agertu zenak, / Bere Pilharra utzi dauku, / Hari berma gaiten denak (Zby RIEV 1999, 399)

b. Pasaiatik etorri zaiku berria Josefa Izagirre [...] bere balkoinerat joanik, han bermatu dela barandari; baina barkalunek amor eman dute eta andre gaixoa erori da (Herr 1962-6-21, 3)

c. Erranez ordreari ginitezen berma, / bertzela etzaikela zarurat arima (Xa Odol 133)

d. [Dassance jauna] behin baino gehiagotan Etchepare adixkidiari bermatu dela, haren argiez, lumaz eta laguntzaz baliatuz (Lf ELit 281)

Kontuan hartzeko moduko aditza da hau, datibodun adibide guztien artean -beti ere perpaus jokatuak badira-, bakar batean baino ez delako datibo komunztadura zaintzen:

(22) Neskatila puntzelez, aldiz, / bermatzen nitzaizie, / zeren puntzela direla orok / zin eginen deizie (AstLas 14)

Adibide honetan, "fidatu, uste ona izan" da aditzaren adiera.

Pentsatu aditzaz ere antzera esan daiteke. Datiboak osagarria markatzeko dakarren berritasuna kontuan hartuta, ez dira asko tradiziotik jaso daitezkeen erakusgarriak. Hala ere, hauetarik batzuk datibo komunztadura gabeak dira (a,b) eta besteak datibo komunztaduradunak (c,d).

(23) a. Berehala, ura ikustearekin, Peyori pentsatu zuen (JEtchep 95 -KG-)

b. Lagun batzueri pentsatzen zuen (JEtchep $65-\mathrm{KG}-$ )

c. Ez zioten deus bertzeri pentsatzen (Jaur 187)

d. ...gal irriskuan nadukanari asko pentsatzen niola (Xa Odol 329)

Ikusi dugunez, datibo-postposizioek berezko lekua betetzen dute datibo komunztadura urratzeko joeran. Ortiz de Urbinak aipatzen dituen ohartu eta urrikaldu aditzekin batera -besterik da sinestu-, fidatu, bermatu eta pentsatu ere aipa daitezke, datibo/postposizio alternantziadun aditzak guztiak. Ez da harrigarria halako datibo-postposizioek datibo komunztadura sarri askotan ez zaintzea, postposizioek ez baitute, definizioz, komunztadurarik eragiten -kontrakoak dirudi harrigarriagoa, datibo komunztadura zaintzeak, alegia.

\subsection{Datibo-osagarri bitxiak: begiratu, jarraiki, segitu eta jazarri adibide}

Jo dezagun orain Ortiz de Urbinak hirugarren eta azkenik bereizten duen datibo sailera. Quirky case edo kasu bitxia deritzana da hirugarren honetan jasotzen duena. Hemen bi dira aipatzen dituen aditzak, jarraiki eta begiratu. Fernándezek (2008) eta Fernández eta Ortiz de Urbinak (2010) datibo-osagarri bitxiak deritzete hauei, eta nagusiki absolutibo/datibo alternantziadun aditzekin 
aurkitzen dira -hala da, behintzat, begiratu, jarraiki, segitu eta jazarri aditzen kasuan.

Begiratu aditzeko adibideak dituzue hauexek, batzuk datibo komunztadurarik gabeak eta besteak komunztaduradunak:

(24) a. Begiraturen naiz bethi zure Ebanjelioko hitzei (Dv LEd 8)

b. Eta ari huni, behar bezala, begiratzen ez banintzan, nire onari bedere begiratu behar nioen (Dv LEd 8)

c. Nola horri ez natzaio begiratu? (Dv LEd 168)

d. Begira, begira zazu ongi asturu gaitz hunen handiari (Dv LEd 212)

Adibide guztiak Duvoisinenak dira, oraingo honetan Liburu ederra (LEd) lanetik jasoak. Duvoisinen idiolektokoa dirudi begiraturen konfigurazio datibodun inakusatiboak (b,c,d) -ikus OEH IV: 464)-, nahiz eta konfigurazio datibodun inergatiboaren erakusgarririk ere baduen (a).

Gutxi dira bere lanetatik aparte aurkitu ditugunak. Hona hemen, pare bat:

(25) a. Othoitz onei begiratzen zaizte, Iauna (CantIzp) ${ }^{20}$

b. Behatu zuen erreposki deputatu guzier (Elsb Fram 107)

Gogoratu begiratu aditzaren testigantzarik ez dagoela zubereraz, eta lapurteraz ere ez duela askorik; behe-nafarreraz, azkenik badira bere testigantzak zenbait idazlerengan (OEH IV: 464). Horrek halako datiboak aurkitzeko aukerak zeharo murrizten ditu.

Begiratu aditzaz esan berri dugunak ez du zerikusi handirik jarraiki aditzaz esan daitekeenarekin. Lehenengo eta behin, asko dira aditzaren beraren testigantzak eta asko, halaber, komunztadura galeraren aztarnak erakusten dituztenak. Jarraiki aditzaz ari garela, sortzen zaigun galdera da ea ez ote dugun datibo komunztadura galerarako joera adiera batzuetan bereziki. Diogun hau oso tentu handiz hartu behar du irakurleak, lehenengo eta behin, gu ez garelako hiztegi kontuetan adituak eta ez dagokigulako, hortaz, adierez hitz egitea. Nolanahi ere, datibo komunztadurarik gabeko testigantza esanguratsuak daude, 'ocuparse de, dedicarse a' adieran (OEH X: 111), eta, espero bezala, ez dira gutxi Duvoisinenak berarenak ere ${ }^{21}$.

(26) a. Iarraikiko zaizte humiltasunari, obedientziari, sinpletasunari (SP Phil 155)

b. Jarraikiko naiz zure Seme maitearen manamendu xoilei (Brtc 75)

c. Asko gizon argitu jarraiki izan dira oihan landatzei (Dv Lab 347)

d. Zure Aitaren xedeari jarraiki zinen (Dv LEd 157)

e. Agintzen darotzut bi urthe osoz zure eskolari jarraikiko naizela (Laph 71)

f. Erretratuz gero beti jarraiki dela meza horri (HU Aurp 184)

Esan gabe doa adiera berean, datibo komunztaduradunak ere aurki ditzakegula. Hona pare bat adibide baino ez:

(27) a. Zarraizko othoitzari, zarrizkote obra onei (He Gudu 125)

b. Edateko ohitzari darraiona luzesko / haren esklabo dagola (Gy 103)

Adiera honetan, irakurlea ohartuko zenez, hurbil samar dago jarraiki goian aztertu ditugun aspektu progresiboko aditzetatik. Hortaz, neurri handi batean, adiera honetako jarraiki aditzak galerarako joera erakustea espero izatekoa da. Komunztadura zaintzen dutenen artean, dena den,

20. Berau ere, Duvoisinen erakusgarriez gain, salbuespena da konfigurazio inakusatibo datibodunaren hautaketan.

21. Ortiz de Urbinak jasotzen dituen Ardiari ongi nahi da jarraiki (Dv Lab 269) Ene solasari jarraik zaite beraz ongi (Dv Lab 311) eta Artzainak arthoski jarraitu behar du erditzekotan diren ardiei, eta antxuei berreziki (Dv Lab 272) adibideak ere era honetakoak direla esango genuke. 
nabaria da forma sintetikoen agerpena, adibideok ere erakusten dutenez -ikus Ortiz de Urbina (1995) forma sintetikoen eta analitikoen arteko ezberdintasunetarako.

Susmoa dugu, esate batera, "seguir (a), imitar (a), ir detrás de alguien o de algo; ser partidario de alguien o de algo" adiera hutsean, gehiago zaintzen dela datibo komunztadura, goian eman dugun beste adieran baino.

(28) a. Bederatzi urte hautan jarraiki zauzkigun irakurtzaileetarik zenbeiti (HU Zez 80)

b. Ezen buraso dohatsu hek ere jarraiki zitzaizkon beren haurrari (Jnn SBi 69)

c. Ene borondatea berraikio zureari (SP Imit III, 15, 1)

Ez du horrek esan nahi datibo komunztadura adiera honetan ere urratzen ez denik:

(29) a. Jarraiki ziren beraz aintzina izar hari (Jnn SBi 16)

b. Eni jarraikitzen dena eztabila ülhünpian (Mst I 1, 1)

c. Hitzemaiten dio haren banderari jarraikiko dela, haren erran guzier behatuko dela (Laph 23)

Duvoisinek bietara erakusten du aditza baita adiera honetan ere, espero izatekoa dena, bestalde:

(30) a. Dohatsuak bertze emakume, Jaunari nigarrez jarraiki zirenak (Dv LEd 13)

b. Zuri, nere Jesus ona, behar natzaitzu jarraiki (Dv LEd 57)

Honaino, beraz, Ortiz de Urbinak aipatzen dituen bi aditzez esan dezakeguna. Gogoratu absolutibo/datibo alternantziadun aditzak direla biak (Fernández eta Ortiz de Urbina 2010), adieraren araberako alternantziaduna lehena eta alternantzia osokoa bigarrena. Sorta berekoa da baita segitu aditza ere, adibideak asko ez diren arren, eta direnak, ez nahi genituzkeen bezain argiak (b,c):

(31) a. Zertako etziñen haren begirakortasunari segitzen? Baiñan ahalke gaixto batek eta balenorioak ezarri zituzte zorigaitz hortan (Dv Telem $157-\mathrm{KG}-$ )

b. Zuk segi-azu zureari (Larz PaperMen 216-KG-).

c. Bertzeak bezain airos ez naiteke segi laguneri (Elzb Po 216)

d. Nola birundan arbolari / dan segitzen itzala (Elzb Po 200)22

Segituren (b) eta (c) adibideetan, agintera eta ahalera agertzen zaizkigu, hurrenez hurren. Datibo komunztadura galera, predikatuei eurei ez ezik, moduari ere egotz dakiokeela uste dugu guk, subjunktibo, ahalera eta aginterazko formetan nabarmenagoak baitira galeraren aztarnak (Fernández eta Ortiz de Urbina 2008). Bestalde, (d) adibidea hitz neurtukoa izateak izan lezake zerikusia komunztadura galeran. Kontuz hartu beharra dago beraz.

Datibo-osagarri bitxiko adiztzat har daiteke, gure ustez, baita jazarri ere. Absolutibo/datibo alternantzidun aditza da, eta alternantzia hori adieren araberakoa da, begiraturena bezala, Fernández eta Ortiz de Urbinaren (2010) ustez. Datibo komunztaduraren hautazkotasun nabarmena erakusten du jazarrik. Hona hemen zenbait adibide, komunztadurarik gabeak (a,b,c) eta komunztaduradunak $(\mathrm{d}, \mathrm{e})$ :

(32) a. [Zure anaier] jazarriz, izpiritu Sainduari jazartzen zare (Laph 1859)

b. [Oraiko minixtro eta deputatuak] guziz jazarri dire Igandeari (Arb Igand 71)

c. Zueri zer-nahi gisetarat jazarriko dena Niri jazarriko da! (Zerb IxtS Io 15, 20)

d. Nere ariman, jazarri behar natzaiote tentazionerik borthitzenei (Jnn SBi 80)

22. Hona adibidea osorik: Nola birundan arbolari Dan segitzen itzala, Bakhotxak hala sor-lekhua Bethi maitha dezala! Anaiak gaituk Eskualdunak, Orai ere, oxala, Jartzen bagine «Guziak bat» Lehenago bezala! (Elzb Po 200). 
e. Gaixtaginak zitzaizkon / Jesusi jazarri (Zby RIEV 1908: 208)

(a) adibidean, datibo komunztadura eragozten duena Pertsona Kasuaren Muga (Albizu 2001) dela pentsa daiteke, baina konturatuko zen entzulea (d) adibidean muga berak ez duela datibo komunztadurarik gabeko formarik ekarri.

Hori baino interesgarriagoa da, gure ustez, azpimarratzea datibo komunztadura horren hautazkotasunaren aztarnak datibodun inakusatibo modura jokatzen duenean aurkitzen ditugula nagusiki -goiko adibideetan (32) - eta ez dela hautazkotasun horren aztarnarik datibodun inergatibo moduko konfigurazioa erakusten duenean, ondoko adibideetan bezala:

(33) a. Debruari jazarri behar dioen eta hura bentzutu behar duen emazte hazkar eta borthitza (Marll 94)

b. Etsai bati bezala jazarri darotazu; eta etsaia izan banintz, gogorkiago ezin jazarriko zinarotan (Dv LEd 95)

c. Frantses gazteak ere izatu zituen beraz tentazioneak, eta jazarri zioten gehienei aski errexki (Jnn SBi 164)

Aditzok absolutibo/datibo alternantziadunak izanik eta datibo-osagarri bitxikoak, igurikik ere datibo komunztadurarako joerarik duen begiratu dugu, baina OEHn, behintzat ez dugu halakorik aurkitu. Horretarako arrazoia historikoa izan daiteke: iguriki iparraldeko tradiziokoa dela diosku OEHk (IX: 203), XVIII. mendera arte datibodun osagarria erakusten zuela eta ordutik aurrera absolutibodun osagarria orokortu zela, salbuespenak salbuespen -Duvoisin. Hortaz, absolutiboaren erabilera orokortu bazen datibo komunztaduraren galera baino lehenago, ulertzekoa da igurikik halako datibo komunztadura gabeak ez erakustea.

Honaino, datibo-osagarri bitxiak absolutibo/datibo alternantziadun aditzetan. Dena den, ez dugu uste datibo-osagarri bitxi hauek halabeharrez alternantziadun aditzetan agertzen direnik, bai baitira alternantziarik izan gabe ere, datibo osagarri bitxiak hautatzen dituzten aditzak eta komunztaduraren hautazkotasun bera erakusten dutenak, gainera. Ez ditugu hemen banaka-banaka aztertuko, eta bat bakarra aipatuko dugu erakusgarri modura: oldartu.

(34) a. Hortan zen bildotxari / oldartu otsoa (Zby RIEV 1908, 759)

b. Hari zaio deabruari oldartzen ohoin eta ebastaile bat bezala (Lap 117 (V 54))

Aurrerago ikusi beharko da zein diren alternantziadunak izan gabe ere, komunztadura galerarako joera dutenak.

\section{Datibo komunztadura beti zaintzen denean (edo datibo komunztaduraren ezinbes- tekotasuna)}

3.1. Datibo-absolutibo hurrenkeradun inakusatiboak

Goian aztertu ditugun aditzak absolutibo-datibo hurrenkerako inakusatiboak dira. Ondoren dakartzagunek, aldiz, inakusatibo datibodunak izan arren, alderantzizko hurrenkera dute, datiboabsolutibo hurrenkera alegia, eta aurrekoek ez bezala hautazko datibo komunztadura gabe, ezinbesteko datibo komunztadura dute. Harrigarria da literatura berean inon ez aurkitzea azken hauen aipamenik eta ezta euren ezin hautsizko datibo komunztaduraren berri.

Guk hemen garatuko ez dugun arren, begi-bistakoa da, Fernándezek (2007), McFaddenen (2004) lanean oinarriturik bereizitako goi eta behe datiboen artean dagoen asimetria sintaktikoa datibo komunztadurari dagokionez ere berresten dela. Baina utz dezagun hipotesi hau alde batera eta itzul gaitezen gure ildo nagusira. 


\subsubsection{Datibo esperimentatzailedun inakusatiboak}

Datibo esperimentatzailedun inakusatiboak aztertuko ditugu lehenik. Ahantzi (a), laket (b), gertatu (c), gogoratu (d), gaitzitu (e), damutu (f) eta dolutu (g) aditzak Fernández eta Ortiz de Urbinaren (2010) sortatik jaso ditugunak -ikus baita Etxepare (2003). Aditz psikologikoak dira guztiak. Esperimentatzaile theta-rolduna da datibo argumentua, eta estimulua absolutibo argumentua.

(35) a. Eta Jainkoari etzaio ahantziko (Dv Lab 10)

b. Huna zer zaitan niri gehienik laket Eskuaran (Arb Igand 12)

c. Niri orobat gerthaturen othe zait (Dv LEd 156)

d. Hemen gogoratzen ahal zaio norbeiti (Jnn SBi 44)

e. Debruari gaitzitu bide zitzaizkon solhas horiek (Jnn SBi 123)

f. Lopezen adixkider handizki damutu zitzaioten (Laph 90)

g. Hurren laur laurdener dolutzen zaie ere (Gy 203)

Bertan jasotzen ditugun adibideak, ikusten denez, datibo komunztadura ez zaintzeko joera duten idazle lapurtarrenak dira, Duvoisin, Arbelbide, Joanategi eta abarrenak, eta ez da batean ere komunztadura urratzen duen datiborik. Hona dakartzagun adibideak, jakina, guk geuk aukeratu ditugu, eta hipotesiaren araberako aukeraketa interesatua dela pentsa lezake irakurleak, baina ez da hala. Irakurle mesfidatiak jo besterik ez dauka testuetara konturatzeko halako aditzekin batera datibo komunztadura zaintzea ez dela salbuespena legea baino, eta ziur gara, hori testuetan ez ezik, ahozko testigantzetan ere jaso ahal izango da.

Jakina, lapurteraren testigantzak jasotzeak ez du esan nahi galera jasaten duten beste euskalki batzuetan ere antzera gertatzen ez denik. Behe-nafarreraren ondokoetan gertatu (a), laket (b), eta gogoratu (d) aditzez gain, iruditu (c) ere agertzen da, eta guztietan zaintzen da komunztadura:

(36) a. Gorenaz ere neri gertatu zaidana zaio gertatuko hari ere: ase baino gehiago, gosea haunditu irakurtze laster horrekin (Xa Odol 11)

b. Bethi hola gerthatzen da: deusik galtzeko ez duenari lakhet zaio buruzagiz eta gobernamenduz khanbiatzea (Elisb Fram 132)

c. Ixildura labur hau onartze bat iduri zakon gizon hanpurutsuari, eta kantitu gabe urbiltzen zaio nexkatoari soberaxko, futxo (Zub 106)

d. To, gogoratzen zaio bati: guazen Zirkorat, han yostatuko gituk (Zub 111)

Zubereraz ere datibo-esperimentatzailedun inakusatiboetan datibo komunztadura zaintzeko joera garbia dago:

(37) a. Inhurriari kukusoa txipiño iduri ziozu; haren aldian mendi bat dela uste dizu (Arch Fab 183)

b. Barbaro haier huna gitia behar ziek aren dolütü (Xarlem 755)

Ez ditugu orain aditz guztiak banaka-banaka begiratuko, baina hemen bildutakoa laburra izanik ere, erakusgarri nahikoa sendoa delakoan gaude ${ }^{23}$. Asimetria egon badago, beraz, eta

23. Salbuespen bat bakarra aurkitu dugu Tartasen lanean gertatu aditzarekin: Hala gertatu zen bost birjina zuhurrer, hek bere ohoria jinkoagati begiraturik, esposaren banketian honki jin izan ziren (Tt Onsa 77). Kasu honetan, Jon Ortiz de Urbinak ohartarazten gaituenez, komunztadurarik eza datibo argumentua zehazgabea izateari egotz dakioke -ikus honi dagokionez, Etxepare eta Oihartzabal (2008a,b) edota Fernández \& Ortiz de Urbina (2008a). 
ukaezina da komunztadurari begira. Dena den, komunztadura beti zaintzen duten datiboak ez dira bakarrik datibo-esperimentatzailedun inakusatibokoak. Begiratu bestela.

\subsubsection{Jabetza besterenezin edo inalienableko datiboak, interes datiboak eta datibo etikoak $^{24}$}

Ezinbesteko komunztadura, gure hipotesiaren arabera, bestelako datiboek ere eragiten dute: jabetza besterenezin edo inalienablea adierazten duten datiboek (a) eta (b), interes datiboek (c) edota datibo etikoek -ikus Etxepare (2003) eta Fernández eta Ortiz de Urbina (2010).

(38) a. Mailez-mail gorphutz guzia kaskaka uspeltzen zaio martir berri huni (Arb Ignd 87)

b. Hala ere, diren bezain bihotz hunkigarri izana gatik aita, ama edo emaztearen alderako hitzak, aita bati bere ume ta haurretan zaio bihotza osoki guritzen, arrailtzen edo eritzen (Xa Odol 13)

c. Gaizoari ordian argitzen zaio adimendua, eta dena ulertzen (Zub 39)

Kontuan izan, datibo-esperimentatzaileak ez bezala, azken datibo hauek ez direla aditzen euren berezko argumentuak, ez bada nolabait gaineratutakoak. Diferentzia hau izanagatik ere, ez dugu espero datibo komunztadurari begira, ezberdin jokatzerik. Azterketa zehatzago baten zain, gure hipotesiaren arabera, halako datiboek beti zainduko dute komunztadura.

Gainerakoan, ez ditugu datibo hauek ondokookin nahasi behar. Lehen adibidea Gèzeri (1873: 26) zor diogu, datibo komunztadura galerari buruzko euskal gramatikaren aipamen goiztiarrenetako batean; bigarrena Tartasena da. Konpara itzazue Laphitzen hirugarren adibidearekin.

(39) a. Jatia gizounari beharrezco da

b. Herio terrible hori, izigarri da mundu guzier handier, eta xipier, iustoer, eta iniustoer (Tt Onsa 147)

c. Arrats ontsa zait eni, dio senharrak (Laph 53)

(c) adibideak komunztadura erakusten du, (a) eta (b) adibideek ez bezala. Halako datiboak erraz ordezka daitezke destinatibo postposizioekin, adibidez, jatea gizonarentzat beharrezkoa da - eta emakumeontzat ere bai, bide batez esanda. Igoera gertatuz gero, (c) adibideen modukoak espero genitzake, hau da, datibodun adibideak eta datibo komunztaduradunak, gainera. (b,c) adibideetan, datiboa egon badago, nahiz eta komunztaduragabea den. Halakoetan, litekeena da besterik gabe datiboa ez igotzea, eta horregatik ez eragitea komunztadurarik. Hortaz, antzeko adibideetan datibo komunztaduraren hautazkotasuna da aurkitzea espero duguna.

Antzera esan daiteke baita ondokoez ere. Duvoisinenak dira guztiak:

(40) a. Zure manamenduetan alhatuko dut gogoa, eta zure bideei begira egonen naiz (Dv Ps $118,15-\mathrm{KG}-)$

b. Ene populua ene itzulpenari begira egonen zaio (Dv Os 11, $7-\mathrm{KG}-$ )

c. begira egon nintzaioen, hegalak atheratuak izan zatzaizkoeneraino; eta jaiki zen lurretik, eta gizona bezala oinen gainera jarri zen, eta eman zioten gizon-bihotza (Dv Dan 7, $4-\mathrm{KG}-$ )

24. Argigarriak izan dira eta ezinbestekoak Jon Ortiz de Urbinaren iruzkinak atal honen garapenean. Eskerrak eman nahi dizkiogu horregatik. 
(a) adibideak datiboa bera erakusten du eta komunztadurarik ez; (b) adibideak datibo bera ez ezik, datibo komunztadura ere; (c) adibideak, azkenik, ez du datiboa erakusten, baina bai datibo komunztadura bera. Kasuistika osoa da, beraz, adibide hauek erakusten dutena. Alabaina, halakoak ez dira gure iritziz, ipar-ekialdeko idazleengan bakarrik jaso daitezkeen adibideak. Hemen datibo komunztadura zaintzea ala ez, ez dagokio, gure ustez, hautu dialektal bati, eta hortaz, euskaraz nonahi aurkitu ahal izango ditu gure irakurleak. ${ }^{25}$

\subsection{Araziak}

Egitura arazleak aztertzen direnean, bi dira komunztadurari dagokionez nabarmendu daitezkeen alderdiak. Bata datibodun araziak eragiten duen komunztadurari dagokio, eta hori da, hain zuzen, orain nabarmendu nahi dugun alderdia. Izan ere, datibodun araziek komunztadura inoiz urratzen ez dutelako hipotesia da gurea. Hau da, datibo komunztaduraren hautazkotasuna erakusten duten euskalkietan eta egileengan, araziaren datibo komunztadura zaindu egiten dela uste dugu, eta ez dugu, hortaz, espero eremu honetan hautazkotasunaren aztarnarik aurkitzea. Eta beste alderdia honen ondorioz sortzen da: egitura arazlean ager litekeen beste edozein datibo sintagmak -arazia ez denak, alegia- ezinezkoa izango du komunztadura eragitea, bi datibo komunztadura (sintaktiko) ezinezkoak direlako adizki bakarrean, Deustuko Hizkuntzalaritza Mintegiak (1989) aspaldi samar eta Ortiz de Urbinak (2003) oraintsu erakutsi diguten bezala ${ }^{26}$. Bi datibo lehiatuz gero komunztadura jasotzearren, bakar batek du irabaztekoa, araziak alegia, eta bigarrena komunztadurarik gabea izatera kondenatua dago: honetan ez dago hizkeren arteko aldakortasunik, honetan batasun erabatekoa dago.

Guk egitura arazleetan, lehen alderdiari baino ez diogu begiratuko oraingo honetan, behintzat, hau da, datibodun araziak sistematikoki datibo komunztadura zaintzen duela erakutsiko dugu ondoko adibideetan. Horretarako, bereziki komunztadura galtzeko joera duten hizkera eta egiletara jo besterik ez dago.

25. Ildo beretik, erne (egon) predikatua ere aipa dezakegu. Inesiboa datiboarekin alternantzian erakusten duen predikatua da erne (egon) -Fernández eta Ortiz de Urbina (2010). Datiboa ageri den kasuetan, bietara agertzen da aditz laguntzailea datibo komunztadurarik gabe (a) eta datibo komunztadurarekin batera (b). Inesibo klasikoa da (c) adibideak dakarrena.

(i) a. Ez dut uste ihiztaria erneago dagoen ihiziari, nola Jaun hura Eskualdun beilarien hitz bakhotxari (Arb Igand 8)

b. Eta bere aldetik, Mimi, / saguer baiño erneago zagokion gasnari (Gy 120)

c. Ago beraz bethi erne hitz haukien gañean (EZ Man I 137)

26. Ez dugu eman bezalako datibodun iragankorretan bakarrik pentsatu behar: Salgai nuen landa Mikel salerazi didate gurasoek [niri] (Ortiz de Urbina 2003: 602); baita itxaron edota begiratu alternantziadunetan ere, datibodun osagarria erakusten dutenean: anaiari itxaronerazi didate (Ortiz de Urbina 2003: 602). Era berean, Ortiz de Urbinak ere halakorik ez dakar eta gaiari buruzko literaturan ez dugu honen aipamenik aurkitu, baina ikusi beharko litzateke joan bezalako datibodun inakusatiboetan, arazia absolutiboarekin markatzeko joera duten hizkeretan, ipar-ekialdekoetan bereziki, ea zer gertatuko litzatekeen Anek Jon Kattalini joan arazi bezalako perpausetan: $d u$ behar luke ala dio? Printzipioz hemen ez genuke izango datibo bien arteko komunztadura lehia eta edozein modutan ere, $d u$ datibogabea espero genezake guk. Ikusi beharko hala den, eta hala izanez gero zergatik. 
(41) a. Aita, amak, erran araz diozozute zuen haurreri eta sehieri aditu dutena (Arb Igand 186)

b. Ez da halere aski goiz jaiki gure jauna, eta ez deie jandarmei aski laster lana egin arazi (HU Zez 128)

c. Iñaziok, hitzik erran gabe, Calistori eta Caserori soineko ilhun bat har arazi zioten (Laph 85)

d. Iguzkia yeikitzen abiatu zenean, Madama Elisabetek begiak altxa arazi ziozkan erreginari zeruetako hedoi hori hori, ederki doratuak zireneri (Elsb Fram 100)

e. Harerazten zaio aberiari jenziana zañetik erhaüstürik untza laürden baten erdia (Ip Dial 56)

f. Anaia zaharrenak guzien izenean erregeari jakin arazi zion, orok nahiago zutela hil Jaunaren legea hautsi baino (Zerb IxtS 76)

g. Duela urte pare bat, Mattin kusiari bertsu batzu molda arazi niozkan, (Xa Odol 273)

Adibide hauetan, aditz datibodun iragankorrak -erran (a)-, iragankor soilak -hartu (c,e), altxatu (d), moldatu (g)-, inergatiboak -lan egin (b), eta guztietan araziak datibo komunztadura zaintzen du. (d) adibide bitxia ere horren adierazgarri: bertan bi datibo agertzen zaizkigu, bata arazia, komunztadura eragiten duena, eta bestea leku-datiboa dirudiena, komunztadurarik eragiten ez duena beraz.

\section{Datibo komunztadura inoiz zaintzen ez denean: datibo-postposizioak, datibo-ad- junktuak}

Bada, heldu gara azkenera. Aldagaiaren hirugarren ahora: komunztadura beti zaintzen duten datiboak aztertu ostean, komunztadura inoiz ere zaintzen ez duten datiboak deskubritzea besterik ez zaigu falta. Datibo-postposizioak dira hauek. Goian ere deitura bera erabili dugu, datibo/postposizio alternantziadun aditzez jardun dugunean, baina ordukoak osagarriak ziren, oraingo hauek, berriz, adjunktuak. Ortiz de Urbinak (1995: 585), esate batera, bete-betean adjunktutzat hartzen dituen Duvoisinen (Dv Lab 382) ondokoak dira orain datibo-postposizio hauen erakusgarri:

(42) a. Errana da orduan halako arbolak lehenago zagoen alde berari landatu behar duela

b. Hegoari zagoenak ez duela iphar aldean ongi emanen

c. Arbola zer haizeri baitzagoen xertatzean, gero ere haize berari egon behar da

Duvoisinen adibideetan -edo adibide bakarra, segidan datozen esaldiek osatzen baitute-, landatu alde batera, lau aldiz aipatzen da egon aditza. Orobat, bertan agertzen zaizkigun datibo guztiek lekua adierazten duten adjunktu hutsak dirudite -inesibo postposizioaz ordezka genitzake zailtasun handirik gabe; leku-datiboak deituko diegu. Caminok ere (1997: 375) oso antzeko adibideak dakartza aezkerarako egon aditzarekin berarekin.

Baina ez dugu honengatik pentsatu behar halakoak direnik leku-datibo guztiak eta ezta nagusiki egon aditzarekin aurkitzen direnik -gogoratzea besterik ez dago goian egitura arazlean aipatu dugun begiratu aditzarekin batera zetorrena (41f). Badira, halaber, Ortiz de Urbinak berak aipatzen duen hurbildu aditzaren modukoak ere. Halako leku-datiboek adlatibo postposizioa ekartzen digute gogora. Begiratu, esate batera, (a) adibidea, bizigabeak dira datibo guztiak, adlatiboduna, aldiz, biziduna.

(43) a. Zuek ordean hurbildu zarete Siongo mendiari, eta Jainko biziaren hiriari, zeruko Jerusalemeri, eta asko miletako aingeru multzoaren gana, 23. nausitasuna. (Dv Hebr 12, $22-\mathrm{KG}-$ )

b. Elizatik kanpo dabilana igandetan, ostatuari jarraikitzen da (Arb Igand 129) 
c. Ezen haren izenaren gatik abiatu dire bideari, paganoen ganik deusik ez hartuz (Dv 3 Io $1,7-\mathrm{KG}-$ )

Etxepare eta Oihartzabalek (2008a) mugimenduzko aditzekin batera jasotzen dituzte halakoak, esate batera abiatu ${ }^{27}$ bera, joan eta itzuli.

Ez da halako datiboen aipamenik sarri aurkitzen ez gaiari buruzko literaturan ez dialektologia lanetan. Salbuespen dira gramatikagintzan Ortiz de Urbina (1995), Fernández eta Ortiz de Urbina (2008) eta Etxepare eta Oihartzabal (2008a,b), eta dialektologian, guk dakigula behintzat Camino (1997), gaia xehetasun handiz jasotzen duena, bai ahozko testigantzak ekarriz bai antzeko literatura testigantzen berri emanez. Etxepare eta Oihartzabalen (2008c) mintzagai nagusia izango dira ale honetako euren lanean. Harrigarriro, datibo komunztadura galera erakusten duten hizkeretako testu klasikoak ikusi besterik ez dago halako datibo-postposizioak sarri aurkitzen direla konturatzeko. Guztiak dira, jakina, komunztadurarik gabeak, eta nekez aurkituko ditu gure entzuleak halako datibo-postposizioak komunztadurarekin batera. Honetan bereizten dira beraz datibo/postposizio alternantziadun aditzekin batera agertzen diren datibo-postposizioetatik: haietan komunztadura hautazkoa zen, hauetan, aldiz, sintaktikoki ezinezko -morfologikoki horretarako eragozpenik ez badute ere.

Ez dira, baina, leku-datiboak bakarrik datibo-adjunktuen artean sailka daitezkeenak. Adjunktu hauen modukoak dirudite baita Lafittek (1979: 220) aipatzen dituen ondoko datibodun nominalizazioek ere:

(44) a. Zahartzeari zuhurtzen ari gira

b. Sagarrak ontzeari, gure eliza-pestak ez dira urrun

Lafittek dioenez, datiboaren bitartez balio inchoative ou conditionnelle adierazten duten aditz izenak dira hauek ${ }^{28}$. Hurbil samarrak dirudite Caminok (1997: 376) jasotako ondokoek ere, bere iritziz denbora eta moduaren antzeko zerbait adierazten dutenak.

(45) a. Tzakurrekin fateari ta obeki atratzen dira

b. Ilabetia akabatzeari

c. Aita ellegatzeari

d. Uskaraz izateari

e. Ja ez errateari pues idem

Baita Caminok Belapeirerengandik zubereraz jasotzen duen ondokoak ere:

(46) Zelüko sü haren agartziari bihotzak piztü zaitzen eta garrez bethe, orotan erraiteko JesüsKrist arrapiztü zela (Bp II, 72)

27. Etxepare eta Oihartzabalek (2008a) jasotzen duten abiatu aditzeko adibidean bideari da agertzen den datiboa. Susmagarria da bideari hau. Baita abiatu bera ere, ez baitu, gure arakaketan, behintzat, hauezaz gain, beste inongo erakusgarririk.

28. Zahartzeari eta sagarrak ontzeari halaxe itzultzen ditu frantsesera, hurrenez hurren, "aux approches de la vieillesse (lit. au vieillir)" eta "quand les pommes commencent à murir". 
Baina ez gaitezen luza eta oraineko datuei begira diezaiegun jarraian.

\section{Hiru ahoko aldagaia Ereduzko Prosa Gauren eta erreminta bat: Corsintax}

Tradizioak eskainitako datuez gain, datibo komunztadura galerak egungo erabileran duen presentzia ere neurtu nahi izan dugu. Horretarako, Ereduzko Prosa Gaur (EPG) corpusa baliatu dugu, 2000tik 2006ra bitarteko liburuetako eta prentsako testuak biltzen dituena.

Corpus horren ustiatzeko, jendaurrean estreinakoz gaur aurkeztuko dugun tresna erabili da: Corsintax.

\subsection{Corsintax ${ }^{29}:$ corpus arakatzaile sintaktikoa}

EPG corpusaz orain arte egin den hustuketa eta arakatze lan sistematikoa, batik bat lexikoari eta hiztegigintzari zuzendua izan $\mathrm{da}^{30}$. Corsintax erremintarekin, sintaxiaren aldetik interesgarriak diren aztergaien inguruko datuak ere sistematikoki erauzteko modua dago.

Oraingoz, aditzen portaerak neurtzen dituzten datuak eskaintzen ditu egindako lehen esperimentuak. Horretarako, corpusari lematizatzailea eta segmentatzailea (besteek "zatitzailea" ere deitua, chunker ingelesez) aplikatu zaizkio lehenik, eta ondoren aditz segmentu guztiak multzokatu eta sailkatu dira, ezaugarrien bitartez: segmentuaren burua, paradigma, modalen eta partikulen erabilera, afijazioa eta abar.

Hauek dira arakatzaile sintaktikoaren oraingo datuak:

$\begin{array}{lll}\square & \text { esaldiak } & 2.182 .971 \\ \square & \text { testu hitzak } & 25.106 .538 \\ \square & \text { segmentuak } & 16.717 .283 \\ \square & \text { aditz segmentuak } & 3.227 .734 \\ \square & \text { aditz lema desberdinak } & 4.472\end{array}$

Horrez gain, EPG corpusa ataletan banatuta dago: iturburuaren arabera (liburuak / Herria / Berria), liburuen euskalkia (Ipar / Hego), eta liburuen sorburua (itzulpenak / jatorrizkoak). Azpicorpus horietako bakoitzean aditzek dituzten datuak ere ematen dira.

Gaurkoan, arakatzaile sintaktiko horren emaria beste esperimentu batera egokitu nahi izan dugu: datibo komunztadura galera neurtzea.

\subsection{Erreferentziako abiapuntua: Leonen Imitazionea}

Helburua hiru ahoko aldagaia EPGn aztertzea zenez, metodologikoki egokia iritzi genion gure gai honetarako erreferentziako obra izango zen idazlan baten hustuketa erabatekoa aurrez egiteari. Lanak literatur tradiziokoa izan behar zuen, eta datibo komunztaduraren galerak ageri ohi duen ka-

29. Corsintax Ametzagaiña garatzen ari den prototipoa da. Erabiltzaileen beharrizanak beteko dituen tresna eraginkorra bilaka dadin, lagungarriak zaizkio ikertzaileon ekarpenak eta iradokizunak, eta bereziki ongi etorriak izango dira. Erreminta aski doitua izan bitartean, helbide honetan egongo da prototipoa: http:// weblingua.ametza.com/corsintax/. Erremintaren nondik norakoez berri gehiago jakin nahi duenak, jo beza webgune horretako "Ohar metodologikoak" deritzon atalera.

30. Ikus, Euskara Institutuaren webgunean (http://www.ei.ehu.es) erabilgarri dauden hainbat aplikazio: Egungo Euskararen Hiztegia, Lexikoa Atzo eta Gaur eta Hiztegi Batua Euskal Prosan. 
suistika ahalik eta modurik zabalenean jasoko zuena. KGko corpus arakatzailean zenbait aditz galeradunen bilaketa eginda, ohartu ginen bazela obra bat horietako gehienak jasotzen zituena, beste ezeinek baino gehiago: Leon Leon Berrizarteren Jesu-Kristoren Imitazionea (Turnhout, 1929).

Tresna konputazionalek ezagutzeko moduko testua izan zedin, lehenik eta behin hainbat egokitzapen egin ziren testuan: esate batera, lematizatzaileak ez ditu dauzkitzut edo othoi ezagutzen, eta dizkizut eta otoi bihurtu genituen sortutako ezkutuko testuan.

Testuari arakatzaile sintaktikoa aplikatuta, datibo komunztaduraren galera jasateko esaldi hautagaiak erauzi ziren. Horretarako, esaldiok baldintza bi bete behar zituzten: aditz jokatua (ez ditezen fida, behatzen baitiote) eta datibo sintagma agerikoa izatea (nahikunde onari).

Leonen Imitazionean baldintza horiek betetzen dituzten esaldiak 363 dira. Esaldiok eskuz aztertuta eta berezituta, hauxe izan zen ondorio orokorra: galerarik gabeko esaldiak 201 ziren (\% 55, 37), eta galeradunak $162(\% 44,63)$. Zerrendatu genituen aditz guztiak 51 izan ziren, aparteko sail batean utzita eduki, egon, izan, eta azken bi horiekin osatutako predikatuak (erne egon, higuin izan...). Horietatik, 11 dira aldagaiaren lehen ahoko aditzak; 18 bigarrenekoak, eta 22 hirugarrenekoak. Emaitza horren xehetasunak, txosten honen I. eranskinean topatuko ditu irakurleak ${ }^{31}$.

Erreferentziako obra horren azterketaren ondoren, EPGn arakatze sakona eta zehatza burutu ahal izateko ezinbestekoak ziren irizpideak eta parametrizazioa erabaki genituen.

\subsection{Datibo komunztadura galera Ereduzko Prosa Gaur corpusean}

Jopuntu dugun auzia argitze aldera, EPG osoa aintzat hartu baino, haren barruko azpicorpus bat soilik ebatzi genuen interesgarri: Herria astekariko testuak, eta Iparraldeko idazleen liburuak. Hurrenez hurren, 206.551 eta 56.354 dira atal horietako testuetan dauden esaldiak.

Imitazionearen hustuketak emandako aditzetatik 19 hautatu genituen haien portaera EPGn neurtzeko: aiher izan, amor eman, behatu, bermatu, bihurtu, fidatu / fida izan, galdatu, galdegin, ihes egin, jarraiki, jarraitu, jazarri, josi, kendu, lotu, ohartu, parekatu, segitu eta uko egin.

Leonen erreferentziako obrarekin lehenago egin bezala, hemen ere esaldi hautagaien erauzketa automatikoa egin zen, bestearen irizpide berberez. Denera, 605 esaldi izan ziren ostera eskuz aztertu behar izan zirenak.

Txosten honen II. eranskinean, xehatuta daude erauzketa horren emaitza nagusienak ${ }^{32}$.

Kasualitate hutsa izan badaiteke ere, Leonenean zein EPGko azpicorpusean antzeko portzentajeak ateratzen dira datibo komunztaduraren galera bai/ez aldakortasunari dagokionez: 55,4 vs. 44,6 Leonenean eta 54,7 vs. 45,3 EPGn.

Aditz bakoitzari buruzko datuak aztertuta, zenbaitetan alde handia dago prentsan eta liburuetan egiten den erabileraren artean: aiher izan prentsan galeraduna, eta liburuetan ez; Herrian galerarako joera handiagoa da galdegin, jarraiki, jazarri, kendu, lotu edo uko egin aditzekin; beste batzuetan -behatu, fidatu, ihes egin, josi, ohartu...-, aldiz, aski berdintsua da portaera.

31. Are datu xeheagoak daude "Datibo komunztaduraren galera Leonen Imitazionean" dokumentu elektronikoan (http://weblingua.ametza.com/corsintax/LeonImitazionea-dat-kmz.pdf); aintzat hartutako 363 esaldiak zerrendatzen dira bertan, aditzez aditz multzokatuta eta komunztadura zaintzen duten edo ez bereizita.

32. Nabardura gehiago nahi duenak -adibide guztien errolda, aditz bakoitzaren inguruan multzokatutadokumentu elektroniko honetara jo dezala: "Datibo komunztaduraren galera EPGn" (http://weblingua. ametza.com/corsintax/EPG-dat-kmz.pdf). 
Datuok arretaz aztertzea beste abagune baterako aproposagoa den arren -gaurkoa amai dezagun-, hona hemen esperimentu honetatik atera ditugun ondorioak, guretzat aski garbiak direnak:

- Tradiziotik egungora, ez dirudi datibo komunztaduraren galerak behera egin duenik. Gora egin duela esatea -eskura dugunaren arabera- gehiegi litzateke, baina egon, bizibizirik dago.

口 Erabat alderantzizko datuak sortzen dituzte prentsako testuek eta liburuetakoek. Herria astekarian dat-kmz bai/ez proportzioa 35/65 den bitartean, Ipar idazleen liburuetan 72/28 dugu proportzio beraxe. Oso deigarria eta esanahi handikoa iruditu zaigu desberdintasuna. Garbi dago liburuetan askoz ere gehiago zaintzen dela datibo komunztadura, Herrian baino:

- Oro har, badirudi ahozko hizkeratik gertuago dagoela Herriako hizkera, liburuetakoa baino.

- Askoren ustez komunztadura galera zuzendu beharreko akatsa da, eta pentsatzekoa da zuzenketa moduren bat aplikatzen dela zenbaitetan, idazleek beren buruari, edota argitaletxeetako zuzentzaileek egina. Nolanahi ere, zuzentasun nahiaren faktoreak azterketa arduratsua behar duen auzia da, eta oraingoan ez dugu horrelakorik egin.

- Emaitzaren zifrak liburuetako egileen arabera aztertuta -ikus II. eranskina- pentsa liteke liburuetako hizkera jasoak baduela zer ikusia komunztadura zaindu beharrarekin. Ildo horretatik, idazlea zenbat eta literatur sisteman integratuago egon, are gehiago zaintzen da datibo komunztadura (Itxaro Borda, Piarres Xarriton...), besteetan baino (Michel Oronoz, Filip Bidart...).

Eta horixe da guztia gaurkoz. Emandako datuek eta azterketarako moduek gerora ere emaitza berriak ekarriko dituztelakoan gaude. Gerokoak gero.

\section{Aipamenak}

Albizu, Pablo. 2001. "Datibo sintagmen izaera sintaktikoaren inguruan: eztabaidarako oinarrizko zenbait datu". In B. Fernández \& P. Albizu (arg.), Kasu eta Komunztaduraren gainean. On Case and Agreement. Bilbo: EHUko Argitalpen Zerbitzua. 49-69.

Camino, Iñaki. 1997. Aezkoako euskararen azterketa dialektologikoa. Iruñea: Nafarroako Gobernua, Hezkuntza eta Kultura Departamentua.

Deustuko Hizkuntzalaritza Mintegia. 1989. "Inkorporazioa perpaus kausatiboetan”. In P. Salaburu (arg), Sintaxi teoria eta euskara. Donostia: EHU. 87-119.

Etxepare, Ricardo. 2003. "Valency and argument structure in the Baque Verb". In J.I. Hualde \& J. Ortiz de Urbina (arg.), A grammar of Basque. Berlin, Mouton de Gruyter. 363-425.

Etxepare, Ricardo \& Bernat Oihartzabal. 2008a. "Dative structures in standard and north-eastern Basque" Licensing conditions at the interface. International Encounter at the Summer Courses of the Uiversity of the Basque Country. XXVI Uda-ikastaroak, Donostia, ekainak 23-24.

Etxepare, Ricardo \& Bernat Oihartzabal. 2008b. "Locational datives and dative agreement in the Eastern Dialects of Basque", European Dialect Syntax Meeting III, Venezia, irailak 18-21. 
Etxepare, Ricardo \& Bernat Oihartzabal. 2008c. "Leku-datiboa ekialdeko zenbait hizkeratan", Aldaketak, aldaerak, bariazioak euskaran eta euskal testugintzan, IKER, abenduak 12-13an.

Fernandez, Beatriz. 1997. Egiturazko kasuaren erkaketa euskaraz. Bilbo: UPV/EHUko Argitalpen Zerbitzua.

Fernández, Beatriz. 2007. High and low datives in Basque bivalent constructions, eskuizkribua, Rutgers.

Fernández, Beatriz. 2008. "Quirky dative objects in Basque", European Dialect Syntax Meeting III, Venezia, irailak 18-21.

Fernández, Beatriz \& Jon Ortiz de Urbina. 2008. "Datibo komunztadura ekialdeko hizkeretan", eskuizkribua, UPV/EHU eta Deustuko Unibertsitatea.

Fernández, Beatriz \& Jon Ortiz de Urbina. 2010. Datiboa hiztegian. Bilbo: UPV/EHUko argitalpen zerbitzua.

Gèze, Louis. 1873. Éléments de grammaire basque. Dialecte souletin. Suivis d'un vocabulaire basque-francais \& francais-basque. Baiona: Imprimerie de Veuve Lamaignère [Birrarg. 1979. Donostia: Hordago.]

Hualde, José Ignacio \& Jon Ortiz de Urbina. 1987. "Reestructuring with ARI." ASJU 21, 425-452.

Hualde, José Ignacio \& Jon Ortiz de Urbina (arg.). 2003. A Grammar of Basque. Berlin: Mouton de Gruyter.

McFadden, Thomas. 2004. The position of morphological case in the derivation: a study on the syntax-morphology interface, doktorego tesia, University of Pennsylvania.

Mitxelena, Luís eta Ibon Sarasola. 1989-2005. Diccionario General Vasco. Orotariko Euskal Hiztegia. Bilbo: Euskaltzaindia.

Mounole, Celine. 2008. "Evolution of the transitive verbs in Basque and apparition of datively marked patients", eskuizkribua, UPV/EHU.

Ortiz de Urbina, Jon. 1995. "Datibo komunztaduraren gainean." In R. Gómez \& J.A. Lakarra (arg.), Euskal Dialektologiako Kongresua (Donostia, 1991ko Irailak 2-6), ASJUren Gehigarriak XXVIII. Donostia: Gipuzkoako Foru Aldundia. 579-588.

Ortiz de Urbina, Jon. 2003. "Causatives." In J.I. Hualde \& J. Ortiz de Urbina (arg.). A Grammar of Basque. Berlin: Mouton de Gruyter. 592-607.

Pikabea, Josu. 1993. Lapurtera idatzia (XVII-XIX). Bilakaera baten urratsak. EHU \& Kutxa Fundazioa.

Ereduzko Prosa Gaur (EPG).http://www.ehu.es/euskara-orria/euskara/ereduzkoa/

Klasikoen gordailua (KG). http://klasikoak.armiarma.com/

I. eranskina: Datibo komunztaduraren galera Leonen Imitazionean

(http://weblingua.ametza.com/corsintax/LeonImitazionea-dat-kmz.pdf)

\begin{tabular}{|c|c|c|}
\hline \multicolumn{3}{|c|}{ DATU OROKORRAK } \\
\hline $\mathbf{k m z}$ bai & $\mathbf{k m z} \mathbf{~ e z}$ & $\mathbf{d e n}$. \\
\hline 201 & 162 & 363 \\
\hline$\% 55,37$ & $\% 44,63$ & $\% 100$ \\
\hline
\end{tabular}


\begin{tabular}{|l|l|l}
\hline $\mathrm{kmz}$ bai & $\mathrm{kmz}$ ez & orr.
\end{tabular}

\begin{tabular}{|l|l|l|l|}
\hline \multicolumn{2}{|l|}{ 1. INOIZ EZ ZAINDU } \\
\hline abiatu & --- & 1 & 2 \\
bermatu & --- & 11 & 2 \\
fidatu / fida izan & --- & 14 & 3 \\
gogo eman & --- & 1 & 3 \\
hil & --- & 1 & 3 \\
jarraitu & --- & 1 & 4 \\
josi & --- & 2 & 4 \\
katzakatu & --- & 1 & 4 \\
kendu & --- & 1 & 4 \\
parekatu & --- & 1 & 4 \\
utzi & --- & 1 & 4 \\
\hline
\end{tabular}

\section{BATZUETAN ZAINDU}

\begin{tabular}{|c|c|c|c|}
\hline amor eman & 1 & 1 & 5 \\
\hline behatu & 13 & 3 & 5 \\
\hline bihurtu & 2 & 3 & 6 \\
\hline egin & 5 & 2 & 6 \\
\hline eman & 14 & 9 & 7 \\
\hline erakatsi & 1 & 1 & 7 \\
\hline erakutsi & 2 & 2 & 8 \\
\hline erran & 5 & 1 & 8 \\
\hline eskaini & 1 & 2 & 8 \\
\hline galdatu & 2 & 2 & 8 \\
\hline iharduki & 1 & 2 & 9 \\
\hline ihes egin & 2 & 3 & 9 \\
\hline jarraiki & 16 & 6 & 9 \\
\hline jazarri & 2 & 2 & 10 \\
\hline lotu & 1 & 6 & 10 \\
\hline mendutu / mendu izan & 1 & 1 & 11 \\
\hline ohartu & 1 & 6 & 11 \\
\hline uko egin & 23 & 6 & 11 \\
\hline \multicolumn{4}{|l|}{ 3. BETI ZAINDU } \\
\hline ageri & 4 & --- & 13 \\
\hline altxatu & 1 & --- & 13 \\
\hline atxiki & 17 & --- & 13 \\
\hline baliatu & 1 & --- & 14 \\
\hline barkatu & 3 & --- & 14 \\
\hline dohaindu & 1 & --- & 15 \\
\hline etorri & 3 & --- & 15 \\
\hline gertatu & 1 & --- & 15 \\
\hline hel egin & 1 & --- & 15 \\
\hline hetsi & 1 & --- & 15 \\
\hline hurbildu & 1 & --- & 15 \\
\hline ideki & 1 & --- & 15 \\
\hline igorri & 1 & --- & 15 \\
\hline ihardetsi & 2 & --- & 16 \\
\hline itzuli & 1 & --- & 16 \\
\hline joan & 18 & --- & 16 \\
\hline kausitu & 1 & --- & 17 \\
\hline koropilotu & 1 & --- & 17 \\
\hline manatu & 1 & --- & 17 \\
\hline mintzatu & 1 & --- & 17 \\
\hline oldartu & 1 & --- & 18 \\
\hline sortu & 1 & --- & 18 \\
\hline
\end{tabular}

\begin{tabular}{|l|l|l}
$\mathrm{kmz}$ bai & $\mathrm{kmz}$ ez & orr.
\end{tabular}

\begin{tabular}{|c|c|c|c|}
\hline \multicolumn{4}{|c|}{ «egon» \& predikatuak } \\
\hline egon & 1 & 30 & 19 \\
\hline aiher egon & --- & 4 & 21 \\
\hline beha egon & --- & 1 & 21 \\
\hline erne egon & --- & 3 & 21 \\
\hline hurbil egon & --- & 1 & 21 \\
\hline so egon & --- & 2 & 21 \\
\hline \multicolumn{4}{|c|}{ «izan» \& predikatuak } \\
\hline izan & 9 & 4 & 22 \\
\hline aiher izan & -- & 2 & 22 \\
\hline ari izan & --- & 1 & 22 \\
\hline aski izan & 3 & --- & 23 \\
\hline atsegabe izan & 1 & --- & 23 \\
\hline atsegin izan & 1 & --- & 23 \\
\hline berdintsu izan & 1 & --- & 23 \\
\hline esker izan & --- & 1 & 23 \\
\hline gaitz izan & 2 & --- & 23 \\
\hline gaitzi izan & 2 & --- & 23 \\
\hline gaizki izan & 1 & --- & 23 \\
\hline gor izan & --- & 1 & 24 \\
\hline gozo izan & 1 & --- & 24 \\
\hline gozoa izan & 1 & --- & 24 \\
\hline hastio izan & 1 & --- & 24 \\
\hline higuin izan & 3 & --- & 24 \\
\hline iduri izan & 1 & --- & 24 \\
\hline laket izan & 8 & --- & 24 \\
\hline mentura izan & 1 & --- & 25 \\
\hline mintzo izan & 2 & 2 & 25 \\
\hline nagusi izan & 1 & 10 & 25 \\
\hline on izan & 1 & --- & 26 \\
\hline poxelu izan & 1 & 1 & 26 \\
\hline zor izan & 3 & 1 & 26 \\
\hline \multicolumn{4}{|l|}{ «eduki» } \\
\hline eduki & --- & 5 & 27 \\
\hline
\end{tabular}


II. eranskina: Datibo komunztaduraren galera EPGn

(http://weblingua.ametza.com/corsintax/EPG-dat-kmz.pdf).

\begin{tabular}{|c|c|c|}
\hline \multicolumn{3}{|c|}{ DATIBO KOMUNZTADURA } \\
\hline & prentsa & liburuak \\
\hline \multirow{2}{*}{ bai } & 98 & 231 \\
& $\% 34,51$ & $\% 71,96$ \\
\hline \multirow{2}{*}{ ez } & 186 & 90 \\
& $\% 65,49$ & $\% 28,04$ \\
\hline
\end{tabular}

\begin{tabular}{|c|c|c|}
\hline \multicolumn{3}{|c|}{ DATU OROKORRAK } \\
\hline kmz bai & kmz ez & den. \\
\hline 331 & 274 & 605 \\
\hline$\% 54,71$ & $\% 45,29$ & $\% 100$ \\
\hline \multicolumn{2}{|c|}{ aintzat hartutako esaldiak } \\
\hline prentsa & liburuak \\
\hline 284 & 321 \\
\hline$\% 46,94$ & $\% 53,06$ \\
\hline
\end{tabular}

\begin{tabular}{|l|l|l|l|l|l|l|l|l|l|l|}
\hline \multicolumn{7}{|c|}{ ADITZEZ ADITZ } \\
\hline & \multicolumn{7}{|c|}{ denera } & \multicolumn{3}{c|}{ Herria } \\
\hline & kmz bai & kmz ez & portz. & kmz bai & kmz ez & portz. & kmz bai & kmz ez & portz. \\
\hline aiher izan & 3 & 4 & 57,14 & --- & 4 & 100,00 & 3 & --- & 0,00 \\
\hline amor eman & 2 & 2 & 50,00 & 2 & 2 & 50,00 & --- & --- & --- \\
\hline behatu & 33 & 7 & 17,50 & 9 & 3 & 25,00 & 24 & 4 & 14,29 \\
\hline bermatu & --- & 2 & 100,00 & --- & 1 & 100,00 & --- & 1 & 100,00 \\
\hline bihurtu & 4 & 11 & 73,33 & 2 & 11 & 84,62 & 2 & --- & 0,00 \\
\hline fidatu / fida izan & 1 & 10 & 90,91 & --- & 5 & 100,00 & 1 & 5 & 83,33 \\
\hline galdatu & 50 & 4 & 7,41 & 36 & 4 & 10,00 & 14 & --- & 0,00 \\
\hline galdegin & 52 & 12 & 18,75 & 16 & 11 & 40,74 & 36 & 1 & 2,70 \\
\hline ihes egin & 4 & 5 & 55,56 & 2 & 2 & 50,00 & 2 & 3 & 60,00 \\
\hline jarraiki & 57 & 19 & 25,00 & --- & 14 & 100,00 & 57 & 5 & 8,06 \\
\hline jarraitu & 1 & ---- & 0,00 & --- & --- & --- & 1 & --- & 0,00 \\
\hline jazarri & 12 & 8 & 40,00 & 3 & 5 & 62,50 & 9 & 3 & 25,00 \\
\hline josi & --- & 5 & 100,00 & --- & 3 & 100,00 & --- & 2 & 100,00 \\
\hline kendu & 24 & 3 & 11,11 & 9 & 3 & 25,00 & 15 & --- & 0,00 \\
\hline lotu & 45 & 128 & 73,99 & 9 & 93 & 91,18 & 36 & 35 & 49,30 \\
\hline ohartu & 4 & 35 & 89,74 & 1 & 11 & 91,67 & 3 & 24 & 88,89 \\
\hline parekatu & --- & 1 & 100,00 & --- & --- & --- & --- & 1 & 100,00 \\
\hline segitu & 1 & 1 & 50,00 & --- & 1 & 100,00 & 1 & --- & 0,00 \\
\hline uko egin & 38 & 18 & 32,14 & 10 & 13 & 56,52 & 28 & 5 & 15,15 \\
\hline
\end{tabular}

\begin{tabular}{|c|c|}
\hline \multicolumn{2}{|c|}{$\begin{array}{c}\text { dat kmz galera liburuetako } \\
\text { egileen arabera }\end{array}$} \\
\hline kopurua & egilea \\
\hline 26 & P. Aintziart \\
\hline 15 & M. Oronoz \\
\hline 14 & P. Xarriton \\
\hline 9 & X. Arbelbide \\
\hline 6 & M. Oxandabaratz \\
\hline 5 & F. Bidart \\
\hline 5 & J.B. Dirassar \\
\hline 3 & E. Touyarou \\
\hline 3 & A. Aintziburu / \\
\hline 2 & J.B. Etxarren \\
\hline 1 & I. Borda \\
\hline 0 & E. Bidegain \\
\hline 0 & A. Arkotxa \\
\hline \multicolumn{2}{|c|}{ D. Landart } \\
\hline
\end{tabular}

\begin{tabular}{|c|c|}
\hline \multicolumn{2}{|c|}{$\begin{array}{c}\text { esaldi kopurualiburuetako } \\
\text { egileen arabera }\end{array}$} \\
\hline kopurua & egilea \\
\hline 115 & P. Xarriton \\
\hline 52 & P. Aintziart \\
\hline 27 & E. Touyarou \\
\hline 22 & I. Borda \\
\hline 18 & $\begin{array}{c}\text { A. Aintziburu / J.B. } \\
\text { Etxarren }\end{array}$ \\
\hline 17 & E. Bidegain \\
\hline 15 & X. Arbelbide \\
\hline 15 & M. Oronoz \\
\hline 13 & J.B. Dirassar \\
\hline 9 & M. Oxandabaratz \\
\hline 7 & F. Bidart \\
\hline 7 & A. Arkotxa \\
\hline 4 & D. Landart \\
\hline
\end{tabular}

\begin{tabular}{|c|c|}
\hline \multicolumn{2}{|c|}{$\begin{array}{r}\text { dat kmz galeraliburuetako } \\
\text { egileen arabera }\end{array}$} \\
\hline portzen. & egilea \\
\hline$\% 100,00$ & M. Oronoz \\
\hline$\% 71,42$ & F. Bidart \\
\hline$\% 66,66$ & M.Oxandabaratz \\
\hline$\% 60,00$ & X. Arbelbide \\
\hline$\% 50,00$ & P. Aintziart \\
\hline$\% 38,46$ & J.B. Dirassar \\
\hline$\% 16,66$ & $\begin{array}{c}\text { A. Aintziburu / } \\
\text { J.B. Etxarren }\end{array}$ \\
\hline$\% 12,17$ & P. Xarriton \\
\hline$\% 11,11$ & E. Touyarou \\
\hline$\% 9,09$ & I. Borda \\
\hline$\% 5,88$ & E. Bidegain \\
\hline$\% 0,00$ & A. Arkotxa \\
\hline$\% 0,00$ & D. Landart \\
\hline
\end{tabular}

